\title{
Priapism: A rare presentation of precursor B-Cell acute lymphoblastic leukemia
}

\author{
Zeliha Güzelküçük ${ }^{1}$, Dilek Kaçar ${ }^{1}$, Rabia Demir ${ }^{2}$, Meltem Kürtül ${ }^{3}$, Hüsniye Neşe Yaralı1 ${ }^{1}$, \\ Namık Yaşar Özbek ${ }^{1}$ \\ Departments of ${ }^{1}$ Pediatric Hematology Oncology, ${ }^{2}$ Pediatric Surgery and ${ }^{3}$ Pediatrics, University of Health Sciences, Ankara \\ Child Health and Diseases Hematology Oncology Training and Research Hospital, Ankara, Turkey. \\ E-mail:drguzelkucuk@hotmail.com \\ Received: 24th May 2018, Revised: 5th September 2018, Accepted: 3rd October 2018
}

\section{Dear Editor,}

A previously healthy 9-year-old boy was admitted to our emergency service with painful erection for the last 18 hours. He had no previous trauma, drug usage or blood disease. Physical examination was unremarkable apart from priapism. Laboratory tests revealed a very high white blood cell (WBC) count $\left(583 \times 10^{9} / \mathrm{L}\right)$, hemoglobin $9.3 \mathrm{~g} /$ $\mathrm{dL}$, platelet count $51 \times 10^{9} / \mathrm{L}$, increased lactate dehydrogenase level (3493 U/L), and prolonged prothrombin time and activated thromboplastin time (16.5 and $30.3 \mathrm{sec}$, respectively). Ninety percent of the cells on peripheral blood smear were L1 type lymphoblasts. Puncture of the corpus cavernosum of the penis provided temporary improvement and together with immediate intravenous hydration, hydroxyurea, allopurinol, and leukapheresis, WBC count decreased to $340 \times 10^{9} / \mathrm{L}$ and priapism resolved. Flow cytometric analysis of bone marrow confirmed the diagnosis of precursor B -ALL and ALL IC-BFM 2009 protocol was started. No further episode of priapism was seen and remission was ensued.

Priapism is abnormal persisting penile erection beyond or unrelated to sexual stimulation lasting more than four hours. ${ }^{1-4}$ The most common cause of priapism in children is sickle cell disease $(65 \%)$, followed by leukemia $(10 \%)$, trauma $(10 \%)$, idiopathic $(10 \%)$, and pharmacologically induced (5\%). ${ }^{4}$ Priapism is seen in $1-5 \%$ of male patients with leukemia. Priapism is a quite rare first presenting symptom in leukemia. ${ }^{5}$ It is mostly seen in patients with hyperleukocytosis with chronic myeloid leukemia (CML), acute myeloid leukemia (AML) FAB M4, M5 and T-cell ALL patients. ${ }^{6}$ CML accounts for $50 \%$ of leukemic priapism. $^{2}$

Symptomatic hyperleukocytosis, which is also called leukostasis is due to abnormal aggregation of leukemic blasts in the capillaries of the microcirculation and may result in lifethreating complications due to impairment of blood flow and/or activation of endothelial wall resulting in tissue hypoxia. Expression of adhesion molecules on leukemic blasts and their response to chemotactic cytokines play an important role in the development of leukostasis. ${ }^{7}$ Lowe et al. ${ }^{8}$ reported 178 children with ALL and hyperleukocytosis and the most common complications were neurological and respiratory; $29 \%$ of these patients were B lineage ALL and none of them presented with priapism. Of interest, despite the fact that our patient had very high blastic load, he did not have any symptom of leukostasis related with the respiratory or neurological systems. His sole manifestation was priapism which was possibly due to venous obstruction of penile blood due to hyperviscosity and microthrombus formation in corpus cavernosa by blastic cells. To the best of our knowledge, our case is the first reported child with precursor B-ALL presenting with priapism. In patients with priapism due to hematologic diseases such as leukemia, aspiration of corpus cavernosum may fail when used alone. Decreasing WBC count with leukapheresis is an effective treatment option in patients with priapism due to hyperleukocytosis.

Key words: priapism, child, leukemia. 


\section{REFERENCES}

1. Hazra SP, Priyadarshi V, Gogoi D, Sharma PK, Pal DK, Chakraborty SC. Pediatric priapism: a rare first manifestation of leukemia: APSP J Case Rep 2013; 18: 39.

2. Nerli RB, Magdum PV, Hiremath SC, et al. Priapism-A rare presentation in chronic myeloid leukemia: Case report. Urol Case Rep 2015; 4: 8-10.

3. Werther R, Oakley E, Heath JA, et al. Priapism as a presentation of T-cell acute lymphoblastic leukaemia in a child. Emerg Med Australas 2004; 16: 425-427.

4. Donaldson JF, Rees RW, Steinbrecher HA. Priapism in children: a comprehensive review and clinical guideline. J Pediatr Urol 2014; 10: 11-24.
5. Akyol Erikçi A, Ozturk A, Sayan O, Bilgi O, Karagöz B Acute lymphoblastic leukemia presented with priapism, Balkan Military Medical Review 2008; 11: 146-148.

6. Mentzel HJ, Kentouche K, Doerfel C, Vogt S, Zintl F, Kaiser WA. High-flow priapism in acute lymphatic leukaemia. Pediatr Radiol 563-560 34;004.

7. Gong J, Wu B, Guo T, Zhou S, He B, Peng X. Hyperleukocytosis: A report of five case sand review of the literature. Oncol Lett 2014; 8: 1825-1827.

8. Lowe EJ, Pui CH, Hancock ML, Geiger TL, Khan RB, Sandlund JT. Early complications in children with acute lymphoblastic leukemia presenting with hyperleukocytosis. Pediatr Blood Cancer 2005; 45: 10-15. 